\title{
Türkçe Öğretiminde Türkiye Türkçesi Ağızları ile Buna Yönelik Öğretmen Tutum ve Görüşleri
}

\author{
Dilek ÜNVEREN \\ Süleyman Demirel Üniversitesi, Eğitim Fakültesi, Türkçe ve Sosyal Bilgiler Eğitimi Bölümü, Isparta \\ dilekkapanadze@sdu.edu.tr \\ ORCID ID: https://orcid.org/0000-0003-3415-9274
}

\begin{tabular}{lrr} 
Araştırma Makalesi & DOI: $10.31592 /$ aeusbed.666691 \\
\hline Geliş Tarihi: 28.12 .2019 & Revize Tarihi: 18.03 .2020 & Geliş Tarihi: 18.03 .2020
\end{tabular}

\section{Atıf Bilgisi}

Ünveren, D. (2020). Türkçe öğretiminde Türkiye Türkçesi ağızları ile buna yönelik öğretmen tutum ve görüşleri Ahi Evran Üniversitesi Sosyal Bilimler Enstitüsü Dergisi, 6(1), 260-278.

\section{ÖZ}

Her ölçünlü dilin temelinde bir ağız vardır. Bu anlamda çalışmada; ağız, diyalekt, varyasyon gibi kavramlar açıklanmış ve ilgili tartışmalar ortaya konmuştur. Türkçe öğretimiyle değişik açılardan birçok çalışma yapılmış olmasına rağmen Türkçe öğretiminde ağız bilimini konu eden detaylı bir çalışmanın olmaması nedeniyle Türkçe öğretiminin sorunları, perspektifi, dil-kültür ilişkisi gibi unsurları bağlamında ağız konusu bu çalışmada ele alınmıştır. Bununla birlikte, Türkçe ders kitaplarında yer alan metinlerde Türkiye Türkçesi ağızlarıyla ilgili olan söz varlığı derlenmiş ve betimsel olarak araştırmada gösterilmiştir. Ayrıca, 151 Türkçe öğretmenine Anadolu Ağızlarına Yönelik Tutum Ölçeği uygulanmıştır. Ek olarak, Türkçe Öğretmenlerinin Türkiye Türkçesi ağızlarının öğrenme-öğretme ortamlarında metinler yoluyla yer verilmesi ve kendi yeterlilikleri bağlamında görüşleri alınmış, veriler içerik analiziyle çözümlenmiştir. Türkçe öğretmenlerinin Anadolu ağızlarının Türkçe derslerinde kullanılan metinlerde yer almasına yönelik olumlu bir tutum ve görüşe sahip oldukları, ancak kendilerini bu alanda yeterli görmedikleri tespit edilmiştir. 5-8.sınıf Türkçe ders kitaplarında ağız özellikleri gösteren söz varlığının bulunduğu da araştırma sonucunda edinilen bulgulardandır.

Anahtar Kelimeler: Türkçe öğretimi, Türkiye Türkçesi ağızları, Türkçe ders kitapları, öğretmen tutumları.

\section{Turkish Dialects in Turkish Teaching and Attitudes and Opinions of Turkish Teachers About it}

\begin{abstract}
In the base of each standard language, there is a dialect. In this context, in the study, concepts such as dialect, accent, variation were explained. Dialectology was examined in the context of Turkish teaching. Despite the fact that there are many studies in Turkish teaching based on different angles, there is no detailed study on Turkish dialects in the context of Turkish teaching. Thus, through this study, the issue of Turkish dialects in Turkish teaching, its perspective, language-culture relationship were discussed. Therefore, texts in Turkish 5$8^{\text {th }}$ course books were examined in terms of their giving place for vocabulary of Turkish dialects, and findings were described. In addition, Attitude Scale towards Anatolian dialects was carried out on 151 Turkish teachers. Moreover, opinions of 29 Turkish teachers were taken in the context of Turkish dialects, their knowledge about them and benefiting from them through texts in Turkish teaching-learning environments. The data collected were analysed through content analysis. As a result, it was found that Turkish teachers have a positive attitude and opinion towards using texts that include vocabulary belonging to Anatolian dialects in Turkish courses to raise awareness about them but they do not see themselves as competent in this area. It was also found that Turkish coursebooks include texts that contain vocabulary of Anatolian dialects.

Key words: Teaching Turkish, Turkish dialects, Turkish coursebooks, attitudes of teachers.
\end{abstract}

\section{Giriş}

Genel olarak ağız "bir dilin veya lehçesinin (dialect) sınırları içinde, belli bölge veya topluluklara özgü sözlü anlatım yollarının bütünü” (Gemalmaz, 2010) şeklinde tanımlanır. Ağız; kökeni aynı olan bir üst sistem olarak ifadesini bulan bir dile bağlı ve doğal oluşmuş, yakın çevre, iş ortamları, okuryazar kimselerin az bulunduğu bir bölgeden çok uzun süre ayrı kalmamış insanlar tarafından sözlü iletişimde kullanılan ancak resmî ortamlarda kullanılmasından kaçınılan, okullarda öğretilmeyen yerel konuşma şeklidir (Demir ve Yılmaz, 2010). Dil bilimsel olarak da bir dil alanı içinde görülen konuşma şekillerini, söyleyiş türlerini, kimi durumlarda da toplumsal özellikleri yansıtan kullanımlar olarak (Vardar, 2000) tanımı yapılan ağız; konuşma dilinin, bölgeler arasındaki özellikle ses farklılıklarına dayalı kolları (Eker, 2015) olarak da ifade edilir. Korkmaz (2017) ise bir 
dilin veya bir lehçenin yazı diline oranla ve çoğunlukla ses bazen de şekil, anlam ve söz varlığı bakımından birbirinden az çok ayrılan yerel konuşma biçimleri olarak tanımlamaktadır. Demir (2002) ise diyalektoloji ve sosyo-linguistik başta olmak üzere dilin varyasyonla ilgilenen kollarının herhangi bir doğal dilde tarihsel, bölgesel, sosyal, kişisel ve durumsal bir çerçevede birbiriyle rekabet hâlinde birden fazla varyantı ortaya çıkardığını ifade eder.

$\mathrm{Bu}$ tanımlamalar ışığında ağız kavramıyla ilgili birtakım kavramların da bilinmesi gerekmektedir. Bunlar: karşılıklı anlaşılabilirlik, ağız sürekliliği, özerklik ve bağımlılıktır. Karşıllkklı anlaşılabilirlik; farklı ama ilişkili varyantların konuşurlarının bir aşinalık, niyetli bir öğrenme durumu ya da özel bir çaba olmaksızın birbirlerini anlayabildikleri diller ve diyalektler arasındaki ilişki biçimi olarak tanımlanır. Karşılıklı anlaşılabilirlikle yakın ilgisi bulunan ăğz sürekliliği ise her bir diyalektin bitişik komşu ile anlaşabilip sürekliliğin sonunda olan diyalektle anlaşamadığında ortaya çıkan durumdur. Başka bir ifadeyle coğrafi bir alan içerisinde birbiri ardınca yer alan farklı noktalardan veri toplandığı takdirde her bir yerleşim yerinin dil özelliklerinin birbirinden farklı olduğu görülecektir. Bir dil ve diyalekt sürekliliği arasındaki ilişkide bağımlılık kavramı ise basitçe özerkliğin tam tersidir. Örneğin, Batı Alman diyalekt sürekliliği üzerindeki bazı çeşitler Hollanda diyalektleri iken, diğerlerine, bu diyalektlerin, standart dillere olan ilişkilerinden dolayı, Almancanın diyalektleridir denir. Hollanda diyalektleri, standart Hollandacaya bağımlıdır, Alman diyalektleri de standart Almancaya bağımlıdır. Bağımlılık ve özerklik, sırf dilsel faktörlerin değil, politik ve kültürel faktörlerin de sonucu olduklarından, değişime açıktır. Öyleyse dil terimini, ona bağımlı olan bütün diğer türleri ile özerk bir tür olarak kullanmaktayız. Çoğunlukla politik gelişmelerin sonucu olarak, bağımlılığın yönü değişebilir, önceden bağımlı olan varyantlar özerklik kazanabilir ve 'yeni' diller gelişebilir (Chambers ve Trudgil, 1998; Ronelle, 2006).

Burada, üzerinde çokça tartışlan ve yer yer birbirlerinin yerine kullanılan varyasyon ve diyalekt kavramlarını da tartışmak gerekmektedir. Diyalekt, en geniş anlamda, belirli bir dilbilimcinin aklındaki herhangi bir konuşma sistemine gönderme yapar. Örneğin, bazı dilbilimciler onu kendi bireysel konuşma sistemlerine göndermede bulunmak için kullanır. Uzman olmayanların gözünde terim; arkaik, tuhaf veya renkli olarak kabul edilen konuşma unsurlarına işaret ederek duygusal imaları taşır. Ayrıca, diyalekt terimi, sosyal tabakalar tarafindan tanımlanan konuşma biçimlerini de ifade edebilir. Terimin en tarafsız kullanımında bir diyalekt kimliği öncelikle coğrafyaya atıfta bulunarak standart olmayan bir dil sistemi olarak tanımlanabilir (Ronelle, 2007). Bu anlamda denilebilir ki diyalekt kavramı iki şekilde kullanılmaktadır. Birincisi standart olmayan dil bilimsel sistemlerin kendi çabalarıyla bireysel diller olarak; diğerinde ise mekânsal farklılaşmanın çeşitli tür ve derecelerine özellikle coğrafya ve dil bilim terimlerine gönderme yapılarak kullanılmaktadır. Yabancı kaynaklarda durum böyleyken Türkçe Sözlük, ağız terimi ile anlamdaş olarak diyalekt teriminin karşıllı̆̆ olarak lehçe ifadesi kullanılmıştır. Talat Tekin (2013) diyalekt kavramını yine Türkçenin lehçeleri bağlamında kullanmıştır.

Dil varyasyonun ise teorik dilbilim içindeki durumu biraz daha karmaşıtır. Genel itibariyle varyasyon başlığı altında ağız kavramı, meslek, yaş, cinsiyet gibi değişkenlere bağlı olarak ele alınmaktadır. Rickford (2002) dilde varyasyon konusunda yerel varyasyon başlığında ağızları gösterir. Dildeki farklılıkların da varyasyonun çıkış noktasına göre değişik ölçülerde gerçekleştiği tespitini yapar ve söz konusu değişkenlerin önemine işaret eder. Dil varyasyonunda bölge, dilin tarihî süreç içindeki gelişimi, etnik köken, meslek eğitim, inanç gibi dil dışındaki değişkenler önemli bir etkiye sahiptir. Bu etkenlerin baskınlık derecesi ile de varyasyonun türü belirlenmiş olur (Demir, 2010). Standart, yerel, sosyal varyasyonlar vd. şeklinde tasnif edilen bu olgu, dilin değişkenliğine de ayrıca vurgu yapmaktadir.

Dil insanların birbirlerine eğilimlerini, fikirlerini, bilgilerini, duygularını aktarabilmelerinin yanında fikirlerini düzenlemelerine imkân tanır. Bununla birlikte, kültürel değerler ve bilgi birikiminin çoğu kuşaklara dil yoluyla aktarılır. Türkiye'de çeşitli kademelerdeki Türkçe eğitimine rağmen öğrencilerin ana dilini kullanmada, kendilerini sözlü ve yazılı olarak ifade etmede sorunlar yaşadıkları bilinmektedir (Alyılmaz, 2010). Bu anlamda sıralanabilecek birçok sorunun yanında dil-kültür ilişkisi bağlamında da Türkçe öğretiminde sorunların olduğu bilinmektedir. Özellikle dilin öğretiminin aynı 
zamanda bir kültür öğretimi olduğu gerçeğinin öğretim programları ve ders kitaplarına tam anlamıyla yansıtılmadığ 1 görülmektedir. Özellikle sözlü kültür ve dil bağlantısı bu anlamda önemlidir. Bir ulusun yüzyıllar boyu yaşadıkları, yazıya geçsin ya da geçmesin onun diline, atasözlerine, masallarına, söz varlığına yansır. Kültür değerlerini yüzyıllar öncesinden yansıtan, Türk dilinin anlam yönünden çok zengin bir dil olduğunu gösteren yapılar vardır (Ünalan, 2014). İşte bu yapıların hepsi ölçünlü dilde yer almamış, bazıları sadece ağızlarda yaşarken bazılarında derleme çalışmaları yapılmış, yazıya geçirilmiş olsa bile yaygınlaşmamıştır. Bu bakımdan dil, sadece iletişimsel görevi olan bir kavram değil; aynı zamanda toplumsal belleğin taşıyıcısı, çeşitliliğin göstergesi ve kimliğin inşacısıdır.

İşte bu nedenle Türkiye Türkçesi ağızları ses, dizim, yapı, söz varlığı özellikleri bakımından yalnız dil araştırmacılarına değil sosyoloji, kültür, tarih ve etnoloji bakımından da yeni alanlar açmaktadır. Dolayısıyla, ağız malzemesi, sadece etimolojik, dil bilimsel çalışmaların nesnesi olmaktan çıkarılıp kültürel değerlerin öğretilmesi ve aktarılmasında, eğitim-öğretim süreçlerinin bir parçası haline getirilmelidir. Korkmaz (2007) ağızları Türk dilinin eski kültür mirasının Anadolu ağızlarındaki devamı olarak görmekte, ağızların yazı dilinin bağlayıcı etkilerinden uzak kalması nedeniyle, Türk boylarının Anadolu'ya Orta Asya'dan getirdiği eski dönemlere ait söz varlığını büyük ölçüde koruduğunu, ifade etmektedir. Bu itibarla ağızlar kültürel belleğimizin çok önemli bir tarafinı oluşturmaktadır.

Son yıllarda Türkiye'deki araştırmacıların katkılarıyla ağız araştırmalarında derleme-inceleme şeklinde de olsa eserlerin sayılarının ve niteliklerinin arttığı görülmektedir. Bununla beraber belli ölçülerde sınırlandırılmış olsa dahi birçok ağız sözlüğünün de yayımlandığı bilinmektedir. Ağızlarla ilgi yapılan çalışmalarda genel itibariyle, derleme çalışması yapılan yörenin ağız özelliklerinin tespiti ve ilgili ağızın ölçünlü Türkiye Türkçesiyle olan farklılıklarının ortaya konması şeklinde bir yöntem belirlenmiştir. Ancak, bu çalışmalardan, Türkçe dersleri ve öğretmen yetiştirme programlarında yeterince yararlanıldığından söz edilemez. Bu bağlamda, bu çalışmada, Türkçe ders kitaplarında yer alan metinlerdeki Türkiye Türkçesi ağızlarına ait söz varlığı ne kadar varlık bulmuştur, sorusunun cevabi araştırılmış ve öğrenme-öğretme ortamlarında ve materyallerinde Anadolu ağızları söz varlığına yer verilmesinin eğitim-öğretim sürecini ne şekilde etkileyeceği olgusu araştırılarak bununla ilgili tespitler yapıp öneriler sunmak amaçlanmıştır. Ayrıca, Türkçe öğretmenlerinin öğrenme-öğretme ortamlarında Anadolu ağızlarının kullanılmasına yönelik tutum ve görüşlerinin ortaya çıkarılması hedeflenmiştir.

\section{Yöntem}

$\mathrm{Bu}$ bölümde araştırmanın modeli, çalışma grubu, veri toplama araçları, nicel ve nitel veri analizine ilişkin bilgi verilmiştir. Bu çalışmada, eş zamanlı karma desen kullanılmış, nicel ve nitel veriler aynı anda toplanmış ve değerlendirilmiştir (Creswell, 2003). Türkçe öğretmenlerinden oluşan 151 kişilik gruba tutum ölçeği uygulanmış, bunların içerisinden tesadüfi olarak 29 kişilik bir grup belirlenerek onlara araştırmacı tarafindan geliştirilen 13 sorudan oluşan yapılandırılmış görüşme tekniği uygulanmıştır. Bu teknik, araştırmacının, hipotezini test etmek amacıyla araştırılan kişi ya da kişiler ile yüz yüze gelecek biçimde önceden hazırladığı sorular yoluyla yapılandırdığı görüşmedir (Ekiz, 2015). Bununla birlikte, doküman inceleme yoluyla 2018-2019 eğitim-öğretim y1lı Ortaokul 58. sınıflarda okutulan Türkçe ders kitapları, Anadolu ağızları söz varlığı açısından incelenmiştir.

\section{Çalışma Grubu}

$\mathrm{Bu}$ çalışmanın çalışma grubunu Erzurum ili Aşkale, Aziziye, Palandöken ve Yakutiye ilçelerinde görev yapan ve kendilerine tutum ölçeği uygulanan 151 Türkçe öğretmeni ile bu öğretmenlerden tesadüfi yolla seçilen ve kendileri ile görüşülen 29 kişilik bir öğretmen grubu oluşturmaktadır. 


\section{Veri Toplama Araçları}

Türkçe Öğretmenlerinin kişisel birtakım bilgilerini toplamak amacıyla bir kişisel bilgi formu geliştirilmiştir. 2018-2019 eğitim-öğretim yılı ortaokul Türkçe Ders Kitapları, Anadolu ağızları söz varlığının tespit edilmesine amacıyla taranmıştır. Tarama esnasında, Türkçenin lehçeleri, şive veya yakın lehçelerine ait söz varlığı dışarıda bırakılmıştır. Alanyazın taramasından sonra araştırmacı tarafından geliştirilen görüşme formu soruları aracılığıyla çalışma grubundaki Türkçe öğretmenlerinden seçilen 29 kişinin görüşü alınmıştır.

Çalışmada öğretmenlerin Anadolu ağızlarına yönelik tutumlarını görmek amacıyla Ahmet Pehlivan tarafindan geliştirilen Anadolu Ağızları Tutum Ölçeği kullanılmıştır. İlgili ölçme aracının geliştirilmesi sürecinde yöntem olarak; ölçek maddelerini hazırlama, kapsam geçerliliğinin sağlanması için uzman görüşü alma, deneme uygulaması, güvenirlik ve geçerlik çalışması yapma şeklinde bir yol izlenmiştir (Pehlivan, 2012). Ölçeğin yapı geçerliliğin belirlenmesi için açıklayıcı faktör analizi (AFA) ve doğrulayıcı faktör analizi (DFA) araştırmacı tarafından yapılmıştır. Ölçeğin hangi alt yapılardan oluştuğunun tespitinde yapı geçerliliğini sağlamak amacıyla yapılan açıklayıcı faktör analizi sonunda ölçeğin 4 faktörlü olduğu görülmüş, dört faktörün birlikte açıkladığı toplam varyansın da \%56,40 olduğu araştırmacı tarafından belirlenmiştir. Faktör döndürme işlemi sonrasında maddelerin içerikleri de dikkate alınarak 'ağızların eğitimdeki yeri ve işlevi', 'ağız kullanıcılarına yönelik tutum', ağız kullanımına yönelik duygusal değer' ve 'ağızların statüsü' olmak üzere dört faktör araştırmacıların dikkatine sunulmuştur. İlgili araştırmada AFA sonucu dört faktörden meydana gelen modelin elde edilen verilerle ne derece uyumlu olduğunun belirlenmesi için doğrulayıcı faktör analizi de (DFA) araştırmacı tarafından uygulanmıştır. Yapılan analiz sonucunda elde edilen maddelerin standardize edilmiş faktör yükleri, $\mathrm{t}$ ve çoklu korelasyon kareleri araştırmacı tarafindan gösterilmiş; tüm bu değerlerin $\mathrm{p}<.05$ düzeyinde anlamlı olduğu görülmüştür. Standardize edilmiş faktör yük değerlerinin de .44 ile .88 arasında değişirken çoklu korelasyon kareleri ise .19 ile .67 arasında değiştiği ve yeterli oldukları araştırmacı tarafindan görülmüştür. Ölçek geliştirmenin sonunda; 22 maddeden oluşan, 1-5 şeklinde puanlanabilen 5'li likert tipi kişilerin ağız kullanımı konusunda kendini değerlendirme ölçeği elde edilmiştir. Ölçeğin güvenirliği için Cronbach Alpha iç tutarlılık katsayısı hesaplanmış ve.80 olduğu da tespit edilmiştir (Pehlivan, 2012).

Bu çalışmada ise, Anadolu ağızlarına Yönelik Tutum Ölçeği, önce konunun uzmanı olan kişilere gösterilmiş daha sonra 114 kişiden oluşan bir ön çalışma grubuna uygulanmıştır. Bu kişilerin puanları bilgisayarda istatistik programı ortamına aktarılmış ve güvenirlik analiz yöntemlerinden Cronbach Alpha ile iç tutarlılığına bakılmıştır. Cronbach Alpha; ölçeklerde ve psikometrik testlerde maddelerin birbiriyle tutarlı olup olmadığını ve maddelerin hipotetik değişkeni ölçüp ölçmediğini belirler (Şencan, 2005). Yapılan analiz sonucunda ölçek maddelerinden iç tutarlık katsayısı düşük maddeler çıkarılmış ve testin Cronbach Alpha iç tutarlılık katsayısı .911 olduğu görülmüsstür.

Ölçek 151 kişilik gruba uygulanmış ve ön çalışma grubu için yapılan güvenirlik analizi yapılarak, bu gruba Anadolu Ağızları Tutum ölçeği yeniden uygulanmıştır. Uygulama sonunda alpha değeri 919 olarak tespit edilmiş ve madde çıkarılmasına gerek duyulmadığı görülmüştür. Söz konusu analizler de bu uygulama puanları üzerinden yapılarak aşağıdaki tabloda gösterilmiştir.

Tablo 1

Anadolu Ağızlarına Yönelik Tutum Ölçeği Ön Çalışma Grubu ve Örneklem Grup Cronbach's Alfa Analizi

\begin{tabular}{|c|c|c|c|c|}
\hline $\begin{array}{l}\text { Anadolu Ağızları } \\
\text { Tutum Ölçeği } \\
\text { Cronbach Alfa } \\
\text { Sonuçları }\end{array}$ & $\mathrm{N}$ & Cronbach Alfa & $\begin{array}{l}\text { Standardize } \\
\text { Cronbach Alfa }\end{array}$ & $\mathrm{N}$ \\
\hline Ön Çalışma Grubu & 14 & ,911 & ,910 & 22 \\
\hline Örneklem Grup & 151 & ,919 & 899 & 22 \\
\hline
\end{tabular}


İçerik analizinin güvenirliği ve geçerliği konusunda kaynaklar (Bilgin, 2006; Şencan, 2005), güvenirliğin büyük ölçüde kodlama işlemine bağlı olduğunu belirtirler. Kodlayıcı güvenirliğinin farklı kodlayıcıların aynı metni farklı zamanlarda aynı şekilde kodlamalarına, başka bir deyişle yeniden üretilebilirliğe; kategori güvenirliğinin ise açık seçik olması hususuna vurgu yapar. İçerik analizinin geçerliğini ise amaç ve araçlar arasındaki uygunluğa bağlar. İşte bu nedenlerle görüşme formuna yapılan içerik analizinin güvenirliliği ve geçerliliği için şu süreçler izlenmiştir:

İçerik analizi konusunda uzman kişilerin birbirinden habersiz olarak yaptığı sınıflandırmada her kavram sayısı neredeyse aynı çıkmış ve bu anlamda yeniden üretebilirlik yani değerlendiriciler arası güvenirlik sağlanmıştır. Bununla beraber araştırmacılar tarafından kodlamalar kontrol edilmiş, görüş birliği ve görüş ayrılığı şeklinde de işaretlemeler yapılmıştır. $\mathrm{Bu}$ anlamda güvenirlik hesaplamasında; Miles ve Huberman (1994) formülü kullanılarak araştırmanın güvenilirliği \% 97 olarak hesaplanmıştır. Buradan araştırmanın güvenirliğinin sağlandığı sonucuna ulaşılmıştır.

Anadolu Ağızları Tutum Ölçeğinin geliştirilmesi sürecinde, ölçeği geliştiren araştırmacı tarafından yapısal geçerliliğe bakılmış; değişkenlerin faktör üzerindeki faktör ağırlıklarının yüksek olduğu görülmüştür. Bu da ifade edilen değişkenlerin yap1 geçerliliğine sahip olduğunu gösterir. Ölçeklerin iç tutarlığı aynı zamanda güvenirlik analizinde de kullanılan alfa katsayısı ile belirlenir, bu şekilde hesaplama yapılır. Cronbach Alfa ile elde edilen değerler söz konusu kavramsal alana ait geçerlik katsayılarını ifade eder. Bu anlamda yaplan bu analizle elde edilen değerler ölçeğin geçerliği için de bir veri oluşturmaktadır.

\section{Verilerin Analizi}

Karma desen yaklaşımı gereği toplanan nicel ve nitel verilerin nasıl edildiğine ilişkin bilgi bu bölümde verilecektir.

\section{Nitel Verilerin Analizi}

Araştırmanın çalışma grubunda yer alan Türkçe öğretmenlerinden 29 kişiyle yapılandırılmış görüşme tekniğiyle elde edilen veriler içerik analizi yöntemiyle çözümlenmiştir. İçerik analizi; çeşitli söylemlere uygulanan metodolojik araç ve tekniklerin bütünüdür (Bilgin, 2006). Bu anlamda analitik betimleme ve kodlama yapılmış, kategori ve temalar oluşturulmuştur. Daha sonra çıkarımlar yapılarak betimlemeyi aşan sonuçların ortaya konulması yoluna gidilmiştir.

Türkçe ders kitaplarında (5-8.sınıf) yer alan metinler incelenmiş, metinlerde yer alan Anadolu ağızlarına ait söz varlığı sınıf, metin adı, tema ve tespit edilen söz varlığı şeklinde konunun uzmanı olan kişilere danışılarak, Türkiye Türkçesi ağızları ile ilgili kaynak eserler başta olmak üzere, derleme sözlüğünden de yararlanılarak tespit edilerek betimlenmiştir. Süreçte, başta Tarama Sözlüğü olmak üzere ağız araştırmaları konusunda yayımlanmış olan eserler taranmış, alanın uzmanı kişilerin de görüşleri alınarak söz konusu söz varlığı betimsel olarak gösterilmiştir. Bu söz varlığının hangi ders kitabı ve metinde yer aldığı da ortaya konmuştur. Bu tespitler yapılırken elde edilen ağız malzemesinin standart dili aşan yapıları; söyleyiş hususiyetleri, elde edilen söz varlığının hangi şehre/bölgeye ait olduğu, çeviri yazı kullanım sistemi ve seslerin boğumlanma özellikleri gözetilerek bir aktarma yapılmamış, metinlerde var olduğu şekliyle gösterilmiştir

\section{Nicel Verilerin Analizi}

Ölçme yoluyla toplanmış düzensiz verilerin, yorumlamaya elverişli hale getirilmesi için betimsel istatistikten yararlanılmış, elde edilen verilerin frekans ve yüzde dağılımları tablolar halinde gösterilmiştir. Frekans analizi, birim ve öğelerin sayısal, yüzdesel ve oransal görünme sıklığını ortaya koymaktır (Bilgin, 2006). 
Anadolu Ağızlarına Yönelik Tutum Ölçeği 151 kişilik örnekleme uygulanmıştır. Verilerin parametrik bir testin genel koşullarını karşıladığı görülmüş, ölçeğin ortalama, medyan ve standart sapma değerlerine bakılmıştır.

Ortalama puanları karşılaştırılacak olan örneklemlerin ilişkisiz olması ve veri setinin bağımlı değişkenin her boyutunda normal dağılım göstermesi (Seçer, 2017) nedeniyle bağımsız değişkenin bağımlı değişken üzerinde etkisini belirlemek için SPSS ortamında tek faktörlü varyans analizi ve ttest nicel verilerin çözümlenmesinde kullanılmıştır. Söz gelimi bağımlı değişken olan Türkçe öğretmenlerinin Anadolu ağızlarına yönelik tutumları, bağımsız değişken olan cinsiyetlerine göre anlamlı farklılık gösterip göstermediği belirlenmeye çalışılmıştır. Değişkenler arasındaki bu etki, tanıma formunda yer alan bütün durumların üzerinde araştırılmıştır. Analizlerden elde edilen sonuçlarda anlamlı farkın ortaya çıkması durumunda, farklılığın hangi gruplar arasında olduğunun tespit edilmesi için varyansın homojenliği kontrol edilmiş, homojen olması durumunda çoklu karşıllaştırma testlerinden olan Scheffe testi uygulanmıştır. Scheffe testinin söz konusu farklılığın hangi gruplar arasında olduğunu belirlemediği durumlarda ise yine çoklu karşılaştırma testlerinden Bonferroni testi işe koşulmuştur.

\section{Bulgular}

\section{Türkçe Ders Kitapları Anadolu Ağızları Söz Varlığı ile İlgili Bulgular}

Çalışmaya konu olan Türkçe ders kitaplarındaki bütün metinler taranmış ve Türkiye Türkçesi ağızlarıyla ilgili söz varlığı ortaya çıkarılmıştır. Süreçte, başta Tarama Sözlüğü olmak üzere ağız araştırmaları konusunda yayımlanmış olan eserler taranmış, alanın uzmanı kişilerin de görüşleri alınarak söz konusu söz varlığı betimsel olarak gösterilmiştir. Bu söz varlığının hangi ders kitabı ve metinde yer aldığı da ortaya konmuştur.

\section{Beşinci Sınıf Ders Kitabı:}

- ' '... Şişkin yanına 'tek', içeri göçük yanına 'aç', bir fasulye kesitini andıran yanına 'bey', düzce olan yanına 'eşek' derdik.' (Erdoğan Tokmakçığlu-Oyuncak: 11).

- " Unutma emi?"' (Abdülkadir Bulut- Oyuncakçı Amca: 14).

- "'.. Bu kadar da olmaz. Amma hava attınız canım!" (Elif Akardaş-Bilmeyen Var mı?: 43).

- 'Dah etti, yok. Dahha dedi, gitmez./Düşerim gerilere, iyceden iyceden.' (Fazıl Hüsnü Dağlarca-Mustafa Kemal'in Kağnısi: 49).

- 'Adı ne bunun ăgabeysi? - Mehmet... Emmi."' (Tarık Buğra-Küçük Ağa: 65).

- "Yörelerde boyutlarına göre kopuz, cura, çöğür, tambura, divan sazı gibi değişik isimlerle tanınır." (Yüce Gümüş-Tamburi Cemil Bey Enstrümanları Anlatıyor: 146).

- "Vur ha vur, vur davul baş pehlivan havası."' (Attila İlhan-Cazgır: 208).

\section{Altınct Sinıf Ders Kitabi:}

- 'Kiminin reyhasından geçilmez/ 'Uzun kavak gıcım gıcım gıcılar.' ', (Bedri Rahmi Eyüboğlu-Türküler Dolusu: 53).

- 'Bilmiyorum ne haldayam/ Yol bir dakka miktarınca/Gâh ağlaya gâhi güle.' (Âşık Veysel Şatıroğlu-Uzun, İnce Bir Yoldayım: 57).

- 'Hah, o 'hiç’i al, git şimdi. Kaldı mı alacağın?’' (Nasrettin Hoca-Kaldı mı Alacağın?: 105).

\section{Yedinci Sinıf Ders Kitabı:}

- ''Bir gün bir Yürük beyi, çadırın önüne atılmış bir kilimi görünce yüreği sızlar.' (Mehmet Önder-Anadolu'da Kilim Demek: 106).

- 'Ana ben gidiyom düşmana karşı." (Anonim-Çanakkale Türküsü: 110).

- 'Nine şipit (bazlama) pişiriyormuş.” (Şükrü Elçin-Horoz: 156).

\section{Sekizinci Sinıf Ders Kitabı:}

- 'Babamın gönderdiği haralları (çok büyük çuval) getiriyor çırak.'(Sadık YalsızuçanlarDeğirmende Döner Taşım: 169). 
- 'Aha şu arada toplanıyorlar!'” (Nezihe Araz-Yunus Emre'nin Mezarları: 188).

- 'Dışarıdan rrıba katılanlar pay almazlard1, ırıp tayfası ile reis, gönüllerinden ne koparsa o kadar.' (Sait Faik Abasıyanık-Haritada Bir Nokta: 240).

2018-2019 eğitim-öğretim yılında 5- 8. Sınıf Türkçe ders kitapları; Türkiye Türkçesi ağızları söz varlığ 1 bağlamında taranmış, ağız hususiyeti gösteren sözcükler ve sözcüklerin geçtiği metinler yukarıda gösterilmiştir. Bu yapılar; varlıklara belirli yörelerde verilen isimler, ünlemler, bağlaçlar, yansıma sözler ve bazı fiil formları şeklinde metinlerde yer bulmuştur. Taramada, ağız hususiyeti gösteren ifadelerin sadece bir ya da birkaç ünitede kullanılmadığı, gelişigüzel bir şekilde birçok ünite içerisindeki metinlerde yer aldığı tespit edilmiştir. Bu metinler ilgili ünitenin ders içi metinlerinden birisi olmak beraber serbest okuma parçalarından biri de olabilmektedir. Bununla beraber ağız söz varlığı şiir, öykü, anı, sohbet, deneme, fikra gibi türler içerisinde yer almaktadır.

\section{Tutum Ölçeğine İlişkin Bulgular}

Tablo 2

Anadolu Ağızlarına Yönelik Tutum Ölçeği Ortalama, Medyan ve Standart Sapma Puanlar

\begin{tabular}{ccccc} 
Ölçek & $\mathrm{n}$ & Ortalama & Medyan & Standart Sapma \\
\cline { 2 - 5 } & 152 & 3,6211 & 3,3182 &, 80068
\end{tabular}

22 maddeden oluşan Anadolu Ağızlarına Yönelik Tutum Ölçeği ortalamaları, medyan ve standart sapma değerleri bakımından analiz edilmiş bütün bir ölçeğe verilen cevapların standart sapma değeri 3,6211 olarak bulunmuştur. Söz konusu ölçek maddelerinin düzeyini belirlemek için Hiç Katılmiyorum 1.00-1.80, Katılmiyorum 1.81-2.60, Karasızım 2.61-3.40, Katıliyorum 3.41-4.20, Kesinlikle Katıliyorum 4.21-5.00 puan aralıkları dikkate alınmıştır Elde edilen 3,6211 standart sapma değeri bahsi geçen likerttte KATILIYORUM (4) ifadesine denk gelecek şekilde bir sonuç ortaya çıkarmıştır. Türkçe Öğretmenlerinin bu bağlamda Anadolu ağızlarına yönelik olumlu bir tutum geliştirdiği söylenebilir.

\section{Çalışma Grubuna Ait Sosyo-Demografik Ögeler Frekans ve Oranlar, t-test ve Tek Yönlü Varyans Analizine İlişkin Bulgular}

Tanıma formunda yer alan değişkenler ile Anadolu Ağızlarına Yönelik Tutum Ölçeği sonucu oluşan puanlar arasında bir ilişkinin olup olmadığı araştırılmıştır. Formda yer alan bilgiler frekans sayıları, yüzdelik oranları ile beraber analizlerde gösterilmiştir. Söz konusu analizde bu değişkenler ile tutum puanları arasındaki ilişki ve fark analizi tablolarda bir arada gösterilmiştir.

Tablo 3

Tutum Puanlarının Her İki Cinsiyete Göre t-test Analizi Sonuçları

\begin{tabular}{lcccccc}
\hline Cinsiyet & $\mathrm{n}$ & $\bar{X}$ & $\mathrm{Ss}$ & $\mathrm{sd}$ & $\mathrm{t}$ & $\mathrm{p}$ \\
\hline Tutum & 151 & 3,10506 & 3,1051 &, 17808 & 214,259 &, 000 \\
Cinsiyet & 151 & 1,384 & 1,38 &, 488 & 34,853 &, 000 \\
\hline
\end{tabular}

Tablo 4

Türkçe Öğretmenlerinin Anadolu Ağızlarına Yönelik Tutum Puanlarının Cinsiyete Göre t-test Sonuçları

\begin{tabular}{lrrrcrrr}
\hline Cinsiyet & $\mathrm{n}$ & $\%$ & $\bar{X}$ & $\mathrm{Ss}$ & $\mathrm{sd}$ & $\mathrm{t}$ & $\mathrm{p}$ \\
\hline $\begin{array}{l}\text { Erkek } \\
\text { tutum) }\end{array}$ & 92 & $\% 61$ & 3,11339 & 3,1134 &, 18313 & 163,956 &, 000 \\
$\begin{array}{l}\text { Kadın } \\
\text { (tutum) }\end{array}$ & 59 & $\% 39$ & 3,09169 & 3,0917 &, 17039 & 138,184 & \multirow{2}{*}{000} \\
\hline
\end{tabular}

Tablolar incelendiğinde araştırmaya katılan Türkçe Öğretmenlerinin Anadolu Ağızlarına Yönelik Tutum Ölçeği sonucu oluşan tutum düzeyleri kadın ve erkek öğretmenlerin her ikisinde de 
anlamlı çıkmıştır. Bu bulgu cinsiyet değişkenin Türkçe öğretmenlerinin Anadolu ağızlarına yönelik tutumlarında her iki cinsiyetin de bir etkiye sahip olduğu şeklinde yorumlanabilir.

Tablo 5

Türkçe Öğretmenlerinin Anadolu Ă̆ızlarına Yönelik Tutum Puanlarının Çocukluğunun Geçtiği Yerleşim Yerine İlişkin Tek Yönlü Varyans Analizi

\begin{tabular}{|c|c|c|c|c|c|c|}
\hline \multirow{5}{*}{$\begin{array}{l}\text { Çocukluğun } \\
\text { Geçtiği Yer }\end{array}$} & & Değişken & $\mathrm{n}$ & $\%$ & $X$ & Ss \\
\hline & 1. & Köy & 38 & $\% 25$ & 3.1244 & , 18447 \\
\hline & 2. & İlçe & 48 & $\% 31$ & 3.1042 &, 18325 \\
\hline & 3. & Şehir & 65 & $\% 44$ & 3.0944 &, 17221 \\
\hline & & - Toplam & 151 & $\% 100$ & 3.1051 &, 17808 \\
\hline \multicolumn{2}{|r|}{ Varyans Kaynağ1 } & sd & \multicolumn{2}{|c|}{$\mathrm{KO}$} & $\mathrm{F}$ & $\mathrm{p}$ \\
\hline \multirow{2}{*}{\multicolumn{2}{|c|}{$\begin{array}{l}\text { Gruplar Arası } \\
\text { Grup İci }\end{array}$}} & 0,22 & \multicolumn{2}{|c|}{,011 } & ,338 & ,714 \\
\hline & & 4,735 & \multicolumn{2}{|c|}{,032 } & & \\
\hline \multicolumn{2}{|r|}{ Toplam } & 4,757 & & & & \\
\hline
\end{tabular}

Tablo incelendiğinde Türkçe Öğretmenlerinin çocukluklarının geçtiği yerler ile Anadolu Ağızlarına Yönelik Tutumları arasında anlamlı bir fark olmadığı görülmüştür $\left[\mathrm{F}_{(5-1018)}=, 714 \mathrm{p}>, 05\right]$. Araştırmanın bu bulgusu çocukluğunun geçtiği köy, ilçe ve şehir değişkeninin Türkçe Öğretmenlerinin Anadolu ağızlarına yönelik tutumları üzerinde herhangi bir etkiye sahip olmadığı şeklinde yorumlanabilir.

Tablo 6

Türkçe Öğretmenlerinin Anadolu Ă̆ızlarına Yönelik Tutum Puanlarının Meslek Hayatında Çalıştı̆̆ Yerleşim Yerine İlişkin Tek Yönlü Varyans Analizi

\begin{tabular}{cllcccc} 
& Değişken & $\mathrm{n}$ & $\%$ & & Ss \\
\cline { 2 - 6 } & 1. & Köy & 34 & $22 \%$ & 3,139 & 0,18249 \\
& 2. & İlçe & 17 & $11 \%$ & 3,0802 & 0,1932 \\
Meslek Hayatında & 3. & Şehir & 11 & $7 \%$ & 3,0909 & 0,17487 \\
Çalıştı̆̆ & 4. & Köy-ilçe & 19 & $13 \%$ & 3,1268 & 0,18716 \\
Yerleşim Yeri & 5. & Köy-şehir & 35 & $23 \%$ & 3,0961 & 0,1804 \\
& 6. & İlçe-şehir & 21 & $14 \%$ & 3,0952 & 0,17481 \\
& 7. & Köy-ilçe-şehir & 14 & $10 \%$ & 3,0714 & 0,15818 \\
& \multicolumn{2}{l}{ Toplam } & 151 & $100 \%$ & 3,1051 & 0,17808
\end{tabular}

\begin{tabular}{llllll}
\hline Varyans Kaynağı & sd & KO & F & p & $\begin{array}{l}\text { Fark } \\
\text { (scheffe) }\end{array}$ \\
\hline Gruplar Arası &, 082 &, 014 & 8,105 & $.000^{*}$ & $1-2$ \\
Grup İçi & 4,675 &, 032 & & & $1-4$ \\
Toplam & 4,757 & & & & \\
\hline
\end{tabular}

Tablo incelendiğinde Türkçe Öğretmenlerinin meslek hayatlarında çalıştıkları yerler ile Anadolu Ağızlarına Yönelik Tutumları arasında anlamlı bir fark olduğu görülmektedir [F (5-1018)= $8,105 \mathrm{p}<, 05]$. Anlamlı farklılıkların hangi yerleşim yeri arasında olduğunu belirlemek amaciyla Scheffe çoklu karşıllaştırma testi yapılmıştır. Scheffe testi sonuçlarına göre meslek hayatında köy yerleşim yerinde öğretmenlik yapanların $(\bar{X}=3,1390)$, ilçede $(\bar{X}=3,0802)$ ve hem köy hem ilçede ( $\bar{X}=3,1268$ ) ifadelerini işaretleyen Türkçe öğretmenlerinin Anadolu Ağızlarına Yönelik tutumlarının daha olumlu olduğu görülmüştür.

Tablo 7

Türkçe Öğretmenlerinin Anadolu Ağızlarına Yönelik Tutum Puanlarının Anne Eğitim Durumuna İlişkin İlişkin Tek Yönlü Varyans Analizi

\begin{tabular}{ccccc} 
Değişken & $\mathrm{n}$ & $\%$ & $\bar{X}$ & Ss \\
\hline 1. İlkokul/ortaokul & 97 & $\% 64$ & 3,1153 &, 18194
\end{tabular}




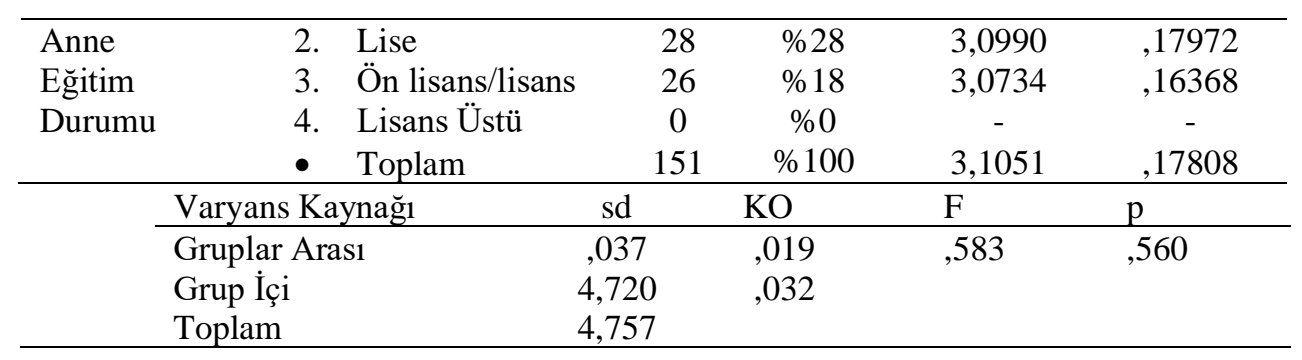

Tablo incelendiğinde Türkçe Öğretmenlerinin anne eğitim düzeyleri ile Anadolu Ağızlarına

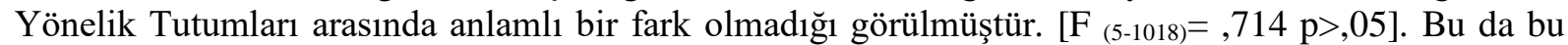
değişkenin Anadolu ağızlarına yönelik tutumları üzerinde farklılaşma yaratmadığı şeklinde yorumlanabilir.

Tablo 8

Türkçe Öğretmenlerinin Anadolu Ağızlarına Yönelik Tutum Puanlarının Baba Eğitim Durumuna İlişkin İlişkin Tek Yönlü Varyans Analizi

\begin{tabular}{|c|c|c|c|c|c|c|}
\hline \multirow{6}{*}{$\begin{array}{l}\text { Baba } \\
\text { Eğitim } \\
\text { Durumu }\end{array}$} & Değişken & $\mathrm{n}$ & \multicolumn{2}{|l|}{$\%$} & $\bar{X}$ & Ss \\
\hline & 1. İlkokul/ortaokul & 85 & \multicolumn{2}{|l|}{$\% 55$} & 3,1144 &, 18365 \\
\hline & 2. Lise & 46 & \multicolumn{2}{|l|}{$\% 47$} & 3,0978 &, 17433 \\
\hline & 3. Ön lisans/lisans & 20 & \multicolumn{2}{|l|}{$\% 21$} & 3,0818 & 16789 \\
\hline & 4. Lisansüstü & 0 & \multicolumn{2}{|l|}{$\% 0$} & - & - \\
\hline & - Toplam & 151 & \multicolumn{2}{|c|}{$\% 100$} & 3,1051 &, 17808 \\
\hline & Varyans Kaynağı & sd & & $\mathrm{KO}$ & $\mathrm{F}$ & $\mathrm{p}$ \\
\hline & Gruplar Arası & ,021 & & 010 & ,323 & ,724 \\
\hline & Grup İçi & 4,736 & & 032 & & \\
\hline & Toplam & 4,757 & & & & \\
\hline
\end{tabular}

Tablo incelendiğinde Türkçe Öğretmenlerinin baba eğitim düzeyleri ile Anadolu Ağızlarına Yönelik Tutumları arasında anlamlı bir fark olmadığı görülmüştür. [ $\left.\mathrm{F}_{(5-1018)}=, 724 \mathrm{p}>, 05\right]$. Bu da bu değişkenin Anadolu ağızlarına yönelik tutumları üzerinde farklılaşma yaratmadığı şeklinde yorumlanabilir.

Tablo 9

Türkçe Öğretmenlerinin Anadolu Ağızlarına Yönelik Tutum Puanlarının Hizmet Yılı Durumuna İlişkin Ilişsin Tek Yönlü Varyans Analizi

\begin{tabular}{|c|c|c|c|c|c|}
\hline \multirow{5}{*}{ Hizmet Y1lı } & Değişken & $\mathrm{n}$ & $\%$ & $\bar{X}$ & Ss \\
\hline & 1. $1-5 \mathrm{y} 1 \mathrm{l}$ & 74 & $\vdots 49$ & 161 & ,18401 \\
\hline & 2. 5-10 y1l & 41 & 27 & 1031 &, 17546 \\
\hline & 3. 10 yil ve üzeri & 36 & $\vdots 24$ & ) 846 &, 17151 \\
\hline & - Toplam & $\lfloor 51$ & 100 & 1051 &, 17808 \\
\hline \multicolumn{2}{|c|}{ Varyans Kaynağ 1} & sd & $\mathrm{KO}$ & $\mathrm{F}$ & $\mathrm{p}$ \\
\hline \multicolumn{2}{|c|}{ Gruplar Arası } & ,024 & ,012 & ,379 & 685 \\
\hline \multicolumn{2}{|c|}{ Grup İçi } & 4,733 & 032 & & \\
\hline \multicolumn{2}{|c|}{ Toplam } & 4,757 & & & \\
\hline
\end{tabular}

Tablo incelendiğinde Türkçe Öğretmenlerinin hizmet yılı değişkeni ile Anadolu Ağızlarına Yönelik Tutumları arasında anlamlı bir fark olmadığı görülmüştür. [F (5-1018)=,685 p>,05]. Bu da bu değişkenin Anadolu ağızlarına yönelik tutumları üzerinde farklılaşma yaratmadığı şeklinde yorumlanabilir.

Tablo 10

Türkçe Öğretmenlerinin Anadolu Ağızlarına Yönelik Tutum Puanlarının Kitap Sayısı Durumuna İlişkin İlişkin Tek Yönlü Varyans Analizi

\begin{tabular}{|c|c|c|c|c|c|}
\hline \multirow{2}{*}{ Anadolu } & Değişken & $\mathrm{n}$ & $\%$ & $\bar{X}$ & Ss \\
\hline & 1. Hiç yok & 15 & $\% 9$ & 3,1485 & ,18057 \\
\hline
\end{tabular}




\begin{tabular}{|c|c|c|c|c|c|}
\hline Ăğzları & 2. $1-5$ aras1 & 102 & $\% 68$ & 3,1065 &, 18165 \\
\hline \multirow[t]{2}{*}{ Kitap Sayısı } & 3. 5 ve üzeri & 34 & $\% 23$ & 3,0816 &, 16702 \\
\hline & - Toplam & 151 & $\% 100$ & 3,1051 & ,17808 \\
\hline \multicolumn{2}{|c|}{ Varyans Kaynağı } & sd & $\mathrm{KO}$ & $\mathrm{F}$ & $\mathrm{p}$ \\
\hline \multicolumn{2}{|c|}{ Gruplar Arası } & ,047 & ,024 & ,743 & ,477 \\
\hline \multicolumn{2}{|c|}{ Grup İçi } & 4,710 & ,032 & & \\
\hline \multicolumn{2}{|c|}{ Toplam } & 4,757 & & & \\
\hline
\end{tabular}

Tablo incelendiğinde Türkçe Öğretmenlerinin Anadolu ağızlarıla ilgili kaç kitaba sahip oldukları ile Anadolu Ağızlarına Yönelik Tutumları arasında anlamlı bir fark olmadığı görülmüştür. [F (5-1018)= ,477 p>,05]. Bu da bu değişkenin Anadolu ağızlarına yönelik tutumları üzerinde farklılaşma yaratmadığı şeklinde yorumlanabilir.

Tablo 11

Türkçe Öğretmenlerinin Anadolu Ăgızlarına Yönelik Tutum Puanlarının Kitap Okuma Sıklı̆̆l Durumuna İlişkin İlişkin Tek Yönlü Varyans Analizi.

\begin{tabular}{|c|c|c|c|c|c|}
\hline \multirow{7}{*}{$\begin{array}{l}\text { Kitap } \\
\text { Okuma } \\
\text { Sıklığı }\end{array}$} & Değişken & $\mathrm{n}$ & $\%$ & \multirow{2}{*}{$\frac{X}{3,1124}$} & \multirow{2}{*}{$\frac{\text { Ss }}{18181}$} \\
\hline & \multirow{3}{*}{$\begin{array}{ll}\text { 1. } & \text { Her gün } \\
\text { 2. } & \text { Haftada 1 gün } \\
\text { 3. } & \text { Haftada birkaç } \\
& \text { gün }\end{array}$} & \multirow{2}{*}{$\begin{array}{c}112 \\
5\end{array}$} & $\% 74$ & & \\
\hline & & & $\% 3$ & 3,1000 & ,18851 \\
\hline & & 34 & $\% 23$ & 3,0816 & ,16702 \\
\hline & 4. Ayda 1 gün & 0 & $\% 0$ & - & - \\
\hline & 5. Diğer & 0 & $\% 0$ & - & - \\
\hline & - Toplam & 151 & $\% 100$ & 3,1051 & 17808 \\
\hline & Varyans Kaynă̆ı & sd & $\mathrm{KO}$ & $\mathrm{F}$ & $\mathrm{p}$ \\
\hline & Gruplar Aras1 & 025 & 012 & 391 & 677 \\
\hline & Grup İçi & 4,732 & ,032 & & \\
\hline & Toplam & 4,757 & & & \\
\hline
\end{tabular}

Tablo incelendiğinde Türkçe Öğretmenlerinin kitap okuma sıklığ1 ile Anadolu Ağızlarına Yönelik Tutumları arasında anlamlı bir fark olmadığı görülmüştür [F $\left.{ }_{(5-1018)}=, 677 \mathrm{p}>, 05\right]$. Bu da bu değişkenin Anadolu ağızlarına yönelik tutumları üzerinde farklılaşma yaratmadığı şeklinde yorumlanabilir.

Tablo 12

Türkçe Öğretmenlerinin Anadolu Ağızlarına Yönelik Tutum Puanlarının Sosyal Çevrelerinde Anadolu Ăgızları Kullanımına Göre t-test Sonuçları

\begin{tabular}{|c|c|c|c|c|c|c|c|}
\hline & $\mathrm{n}$ & $\%$ & $\bar{X}$ & Ss & $\mathrm{sd}$ & $\mathrm{t}$ & $\mathrm{p}$ \\
\hline $\begin{array}{l}\text { Tutum } \\
\text { Puanlar1 } \\
\text { (var) }\end{array}$ & 140 & $\% 93$ & 3,1080 & 3,10799 & 17982 & 205,233 & \multirow[t]{2}{*}{,000 } \\
\hline $\begin{array}{l}\text { Tutum } \\
\text { Puanlar1 } \\
\text { (yok) }\end{array}$ & 11 & $\% 7$ & 3,0636 & 3,06364 & ,15332 & 63,188 & \\
\hline
\end{tabular}

Öğretmenlerin Anadolu Ağızlarına Yönelik Tutum Ölçeği sonucu oluşan tutum düzeylerine bakıldığında sosyal çevrelerinde ağız özellikleriyle konuşan kimselerin olduğu öğretmenler lehine anlamlı bir fark görülmüş, sosyal çevrelerinde böyle kişilerin olmadığı öğretmenlere göre tutum düzeylerinin daha yüksek olduğu tespit edilmiştir. Bu bulgu ağız hususiyetiyle konuşan bir çevrede yetişmiş olma değişkeninin öğretmenlerin Anadolu ağızlarına yönelik tutumlarında olumlu bir etkiye sahip olduğu şeklinde yorumlanabilir. 


\section{Görüşme Verilerine İlişkin Bulgular}

Anadolu ağızlarının Türkçe dersinde kullanımına ilişkin öğretmenler ile yapılan görüşmelerden elde edilen veriler içerik analizine tabi tutulmuştur. Elde edilen kod, kategori ve temalar Tablo 13'de sunulmuş, her bir kategori alt başlıklar halinde detaylı açıklanmış, desteklemek için öğretmenlerin görüşlerine yer verilmiştir.

Tablo 13

Görüs Formu Bulguları

\begin{tabular}{|c|c|c|}
\hline \multicolumn{2}{|c|}{ 1. Tema: Dil, Öğrenme ve Akademik Betimlemeler } & 2. Tema: Söz ve Yaşam \\
\hline $\begin{array}{l}\text { Ağız Kullanımı } \\
\text { ve Eğitim Kategorisi }\end{array}$ & $\begin{array}{l}\text { Alana Dair Yetkinlik } \\
\text { ve Bilgi Kategorisi }\end{array}$ & Duygusal Değerler Kategorisi \\
\hline - Gerekli olma & - $\quad$ Dil bilinci & $\begin{array}{l}\text { - Kendini ifade etme } \\
\text { becerisi }\end{array}$ \\
\hline - Zorunluluklar & - Ağız çalışmalarına katkı & - Türkçe sevgisi \\
\hline - İletişim kurma ihtiyacı & - Hayat boyu öğrenme & - Sosyal ve işlevsel olma \\
\hline $\begin{array}{l}\text { - Oğrenme ortamını } \\
\text { zenginlestirme }\end{array}$ & - Öğretmen yetiştirme & - Ait olma/yabancılaşmama \\
\hline - Kültürel iletişim & - Folklor, etnoloji, tarih & - Kültür farkındalığı \\
\hline $\begin{array}{ll}\text { - } & \text { Kültürü tanıma } \\
\text { - } & \text { Kültür aktarımı }\end{array}$ & - Derleme ve tespit & - Dil kullanımı ve tutum \\
\hline - Kültürel kodlar & & \\
\hline - İfadede kolaylık & & \\
\hline $\begin{array}{l}\text { - } \begin{array}{l}\text { Standart dile katk1 } \\
\text { sağlama }\end{array}\end{array}$ & & \\
\hline
\end{tabular}

\section{Ağız Kullanımı ve Eğitim Kategorisine Ait Bulgular}

Türkçe dersinde seçilecek metinlerin niteliği, ders içeriğinin yapılandırılması hususlarında yapılacak seçimlerin ve çalışmaların, öğrencilerin hem ulusal bir bilinç kazanmasında hem de kişiliğinin oluşmasında önemli bir etkiye sahip olacağı açıktır. Bu anlamda Türkçe ders kitaplarında ve öğrenme-öğretme ortamlarında Türkiye Türkçesi ağızlarına yer verilmesi, bu ağızların gösterilmesi ve bunlara dair bir farkındalık yaratılması konusunda; Türkçe öğretmenlerinin düşüncelerinin öğrenilmesi için sorular sorulmuş, tabloda gösterilen kod ve kategoriler bağlamında şu sonuçlara ulaşılmıştır:

Türkiye Türkçesi ağızlarıyla ilgili akademik düzeyde özellikle lisansüstü tezler, makaleler yayımlanmakla beraber bu eserler daha çok söz varlığını tespit, fonetik, morfolojik ve sentaktik unsurların ortaya çıkarılması ve örneklendirilmesi şeklinde karşımıza çıkmaktadır. Bu bağlamda Türkçe öğretmenleri; öğrencilerin zaten bu türden kullanımlarla hayatın her aşamasında karşılaştıklarını ve bunların ders kitaplarında da yer alması gerektiğini ifade etmişlerdir.

Türkçe ders kitaplarında Anadolu ağızlarına ait söz varlığını ihtiva eden metinlerin bulunması gerektiğini düşünüyorum. Çünkü öğrenciler zaten gündelik hayatlarında hem kendi yöresinin ağız özelliklerini konuşan kişilerle karşılaşmakta hem de TV dizilerinde bulundukları yörenin dışındaki başka ağız özellikleriyle konuşan kişileri görmektedir. (Ö3).

Türkçe ders kitaplarında da tıpkı Türk Dili ve Edebiyatı ders kitaplarında olduğu gibi lehçe, şive ve ağız özelliği gösteren metinlerin bulunması kanaatimce iyi olur. Burada hem orijinal metin hem de standart dile aktarılmış metin bir arada bulunabilir. Ayrıca bir sözlük de oluşturulabilir. Böylece öğrencilerin yöresel ağız kullanım örneklerini görmeleri sağlanabilir. (Ö2). 
Türkçe öğretiminin özel amaçları içerisinde Türkiye Türkçesi ağız özelliklerinin yer aldığg metinlerin bulunmasının başta Türk dilinin inceliklerini, sosyal hayat ve coğrafi unsurlar içerisindeki değişimi ve görünümünü tanımalarına yardımcı olacağını belirtmişlerdir.

\section{Alana Dair Yetkinlik ve Bilgi Kategorisine Ait Bulgular}

Türkçe öğretmenliği programı ile ilgili ortaya konulan önermelerin başında dil dersi içeriklerinin, dilin daha sistemli ve tarihsel serüveninin anlaşılmasına olanak sağlayacak bir yapıda olması gelmektedir. Türk dili tarihinin ve kültürünün temel özelliklerini ve asıl başvuru kaynaklarını merkeze alan bir ders içeriğinin hâlihazırda olmaması Türkçe öğretmenlerinin dil, tarih ve kültür gibi olguları yeterince bilmeden lisans programlarından mezun olmalarına neden olmaktadır. Bununla beraber dil bilim derslerinin salt kuramsal boyutuyla ele alınması, uygulama merkezli bir yaklaşımın benimsenmemesi, alan dil derslerinin ders saati gibi yetersizlikler de yine sayılabilecek problemlerdendir.

Ağız çalışmalarının en önemli yanı dil çalışmalarına yaptığı katkıdır. Ağız araştırmaları gerek malzemenin toplanıp değerlendirilmesi gerekse fonetik, morfolojik, leksik ve sözdizimi özellikleri itibariyle uzmanlık gerektiren bir çalışma alanıdır. Bu nedenle ağız araştırmaları üniversitelerimizde daha çok lisansüstü çalışmalar olarak ele alınmaktadır. Ses, biçim, söz dizimi ve söz varlığına dair ölçütler başta olmak üzere dil konusunda artzamanlı ve eşzamanlı bir bilgi birikimine ve bu çalışmaların sosyo-kültürel amaçlarına vâkıf olmak gerekir. Bu bağlamda Türkçe öğretmenlerinin görüşleri şu şekildedir:

Üniversitede aldığımız eğitim sırasında doğrudan Anadolu ağızlarına yönelik olarak bir ders almadım. Ayrıca ilgi duyduğum bir alan da değil. Türkçe öğretmenlerinin adı geçen kavramlar konusunda da yetkin olduğunu düşünmüyorum. Yine lisans eğitimim sırasında ders aldığım hocalarımın da kendi çalışma alanları dışında bu konular hakkında yüzeysel bir bilgiye sahip olduklarını düşünüyorum. (Ö15).

Türkçe öğretmenliği lisans eğitiminin amaçları içerisinde bu türden bir birikime sahip öğretmenler yetiştirilmesi gerektiğini düşünmüyorum. Bu nedenle fakültede verilen eğitimden dolayı da biz Türkçe öğretmenlerinin ağız araştırmaları ile ilgili yeterli seviyede olmadığımız kanaatindeyim. (Ö: 21)

Türkçe öğretmenleri ve bizi yetiştiren hocalar bu konuda yeterli değil. Çalışma alanlarının bu olmaması ya da başka nedenler olabilir. Ancak bu konular üzerine bir dersin bulunması da bence gerekli. Çünkü Anadolu bu çeşitlilik konusunda yeterince zengin bir coğrafya. (Ö11).

Türkçe öğretmenlerinin ağız bilim, ağız çalışmaları konusunda kendilerini yeterli görmedikleri tespit edilmiştir. Lisans eğitimi sırasında doğrudan Anadolu ağızları ile ilgili bir ders almadıklarından bu konuda asgari bir bilgiye sahip olmadıklarını belirtmişlerdir. Aldıkları ders içeriklerinin ve akademisyenlerin de yeterli/yetkin olmadıklarını ifade etmişlerdir.

Ağızlar üzerine yapılan çalışmalar incelendiğinde araştırmaların doğrudan doğruya dilin geçirdiği değişimleri gösteren bir yapıda olduğu görülecektir. Ağızların sınıflandırılması, başka ağızlarla benzerlikleri ve farklılıkları, ses ve şekil hususiyetleri yapılan çalışmaların temelini teşkil etmektedir. Ayrıca, ağızlar; ait oldukları toplumun ya da grubun kültürel değişimini ortaya koyar. Gemalmaz (1999) ağızların oluşumunda coğrafi koşullar, tarih ve etnik yapının varlığına vurgu yapar. Ağızların sınıflandırılması sürecinde göz ardı edilmemesi gereken bu faktörler aynı zamanda yukarıda ifade edilen kültürel olguların anlamlandırılması için de kapı aralamaktadır. Bu anlamda Türkçe öğretmenlerinden görüşler alınmıștır. Katılımcılar; bu konuda tarih, folklor ve etnografya vurgusu yapmış olmakla beraber öğretmenlerin de en azından derleme çalışmalarına katılıp bu anlamda yapılacak olan çalışmalara görev yaptıkları coğrafi zemin bağlamında katkı sağlayabileceklerini ifade etmişlerdir. Cevaplardan bazıları şu şekildedir: 
Yazı dilinde yer almayan birtakım sözcüklerin kültür değeri taşıdıkları açıktır. Yani ağızlarda yer alan sözcükler tarih ve halk bilim anlamında bir kaynak oluşturmaktadır. (Ö17).

Dil çalışmalarında olmasa bile kültüre dair malzemenin nasıl toplanacağ 1 konusunda biz öğretmenlere eğitim verildiği takdirde, akademik çalışmalara katkı sağlayabiliriz. Derleme konusunda da eğitimler verilebilir. (Ö8).

$\mathrm{Bu}$ bağlamda katılımcılar; Türkçe öğretmenlerinin ağız çalışmaları, ağız çalışmalarının akademik söz varlığı, ağız araştırmalarının akademik benlik tasarımları içerisindeki yeri, dil araştırmaları dışında bu türden çalışmaların hangi değerleri ortaya koymaya yarayacağı yönünde birçok duruma dair görüşleri ifade edilen bulgulara yansımıştır.

\section{Duygusal Değerler Kategorisine Ait Bulgular}

Duyuşsal alan genel itibariyle; duyguların, inanç ve tutumların gerek bireysel gerekse sosyal becerilerin bir arada düşünüldüğü bir boyuttur. Duygular, yönelimler, arzular, değerler, bireysel tercihler hep bu alan içerisinde düşünülür. Kültürel faktörler de bu alanın etkilediği önemli yapılardan biridir. Araştırmada Türkçe sevgisi, ait olma duygusu, kültürel farkındalık gibi kodlar Türkiye Türkçesi ağızlarına yönelik duyuşsal unsurlar olarak bu çalışmaya yansımıştır.

Kültürel zümreler yer yer farklılıklarını korumuş olsa bile küresel dinamikler bu zümrelerin tamamını bir şekilde etkilemektedir. Küreselleşmenin uygulamak istediği ve topluma sunduğu kanon, ağız gibi kültürel bellek, bilgi, farklılık ve çeşitliliğin de ortadan kalkmasına neden olmaktadır. Bununla beraber daha seçkinci yaşam alanları ve kültürel mekânlar bu kültürel zümrelerinin değişmesine yol açmaktadır. Bu durum hem toplumsal belleğin ve kimliğin inşasının önemli bir sacayağı olan dilin ölçünlü olmayan ancak iletişim yetisini ortaya koyan özelliğini ortadan kaldırmakta hem de yabancılaşmaya neden olmaktadır. Bu bağlamda bazı öğretmen görüşleri şu yöndedir:

Özellikle teknolojik gelişmelerin yoğun olmasının bu kültürel değerleri unutturduğunu düşünüyorum. Dil dersleri zaten milli bilincin en iyi aktarılacağ 1 derslerden biridir. $\mathrm{Bu}$ nedenle bölge ağızlarının ders materyallerinde olması gerekir. (Ö28).

İlk görev yaptığım yer bir köy ortaokuluydu. Orada öğrenciler arasında ağız kullanımı yaygındı. İstanbul Türkçesini doğru kullanamadıklarından derse katılmakta sorun yaşıyorlardı. Ancak yöresel ağızlarını kullanmalarına izin verdiğimde derse de katılımın daha fazla olduğunu gözlemledim. Bu nedenle bazı durumlarda öğrencilerin ağız kullanmalarına izin verilebilir. (Ö19).

Derse karş1 tutumun ve özgüvenin geliştirilmesinde eğitim ortamlarında kullanılabilecek birçok yöntemin olduğunu düşünüyorum. Duruma göre ağız özellikleri de kullanılabilir. (Ö7).

Araştırmada; eğitim-öğretim süreci içerisinde bölge ağızlarının öğrencilerin kültürel bilgi, millî bilinç, geleneğe dair duyuşsal gelişimine etkisi konusunda öğretmenlerin görüşü alınmıştır. Bu dilsel malzeme haliyle kültür kodlarına, gelenek ve ulusal bilince ait yapılar barındırmaktadır. Bu odakta katılımc1 görüşleri şu şekildedir:

Türkçe derslerinin içeriği ve ölçünlü dilin olanaklarıyla da milli bilinç ve kültür öğretilebilir, aktarılabilir. Bu nedenle sınıf içerisinde ağız kullanmanın milli bilince, kültürel bilginin artırılmasına ve gelenek bilgisine etki edeceğini düşünmüyorum. (Ö4).

Ağızlarda yaşayan bazı sözcüklerin birer kültür unsuru olduğunu düşünüyorum. Bunlar dil bilinci bağlamında birer kültür yapıs1 olarak 
kullanılabilir. Bunun da öğrencilerin dil ve kültür bilincine katkı yapacağını düşünüyorum. (Ö5).

Küreselleşme ile değişen kültür söylemi, dili toplumun bir yansıması olarak ele almaktan alıkoymamaktadır. Yine ağızların oluşmasındaki etkenler ifade edilirken coğrafya-dil ilişkisi içerisinde yüzey şekilleri gibi; tarih ile ilişkisinde, lehçe, şive gibi unsurlara yer verilir. Bu anlamda birçok değer dizisine sahip olan ağızların, kültür, iletişim, yabancılaşma, sosyal işlev ve Türkçe sevgisi gibi duygusal değerlerle bir arada düşünülmüş olması anlamlı ve önemlidir.

\section{Sonuç, Tartışma ve Öneriler}

Dil bir bağlam içerisinde gelişir ve öğrenilir/edinilir. Bağlamı oluşturan tüm bu dil, değer ve normlara kültür denir (Ünal, Taşkaya ve Ersoy, 2018). Kültür aktarımının en işlevsel aracı dildir; bir dili öğretmek o dilin konuşucusu olan toplumun kültürünü de öğretmektir. Dil üzerinden, kültürel kimliğin yaratılması sürecinde eğitim kurumlarının yeri yadsınamaz. Okullarda bu kimliğin gelişmesinde en önemli pay Türkçe dersi ve kitaplarınındır. Bu anlamda Türkçe ders kitapları başta kimlik inşası, millî duyarlılı̆̆ın ve benliğin oluşması süreçleriyle beraber kültür aktarımında işlevsel bir faktördür.

Buna rağmen, Anadolu ağızlarının eğitim-öğretim sürecinin bir nesnesi olarak yer bulması neredeyse sadece lisans ve lisansüstü programlarında görülmektedir. Bununla ilgili yapılan çalışmalar ise yine lisansüstü çalışmalar düzeyinde olup elde edilen ağız malzemesinin kullanımı ise yine akademik ders kitapları başta olmak üzere bu konu üzerine yapılan çalıştaylar, kongrelerle sınırlıdır. Bununla beraber informal öğrenme ortamlarında yaygın olarak kullanılan ağız ve hususiyetleri aynı zamanda TV dizileri, radyo programları ve tiyatrolarda da kullanılmaktadır. Denilebilir ki formal ve informal öğrenme ortamlarında ağız kullanımıyla bireyler karşılaşmakta, bunları kullanmakta, kitle iletişim araçları vasıtasıyla bireyler sadece bulundukları bölgenin ağız özellikleriyle değil; başka bölgelerin de ağız kullanım şekilleriyle karşılaşmaktadır.

Bugüne değin yapılan Türkiye Türkçesi ağızlarıyla ilgili çalışmalar genellikle şu şekildedir: Saha araştırmasına bağlı olarak elde edilen malzeme, metinler bağlamında ayrıntılı olarak incelenerek derlemenin yapıldığı yerin ağız özelliklerinin ortaya çıkarılması yönünde derleme ve inceleme çalışmalarının yanı sıra elde edilen malzeme dilbilgisi alanında incelenmiş ve sözlükler hazırlanmıştır. $\mathrm{Bu}$ çalışmalar bibliyografik eserler şeklinde de araştırmacıların dikkatine sunulmuştur. Bu konuda geniş bilgi için bkz. Anadolu A ğızları Bibliyografyası ve Türkiye Türkçesi Ağızları Bibliyografyası (Buluç, 1942; Gülensoy ve Alkaya, 2010). Bununla birlikte ağız araştırmalarının sorunları, derleme çalışmalarının yöntemleri, ağız-etnik yapı ilişkisini merkeze alan araştırmalar, yöntem sorunları, konuşma ve yazı dili ilişkileri, karşılaştırmalı ağız araştırmaları, ağız tezleri için öneriler, artsüremli ve eşsüremli çalışmalar da gerçekleştirilmektedir (Akar, 2006; Buran, 2002; Demir, 2012; Gülsevin, 2010; Karahan, 2000; Korkmaz, 1995).

Ağız özelliklerinin Türkçe öğretimindeki yeri farklı ve yeni bir alandır. Bununla ilgili olarak yükseköğretim düzeyinde; eğitim fakülteleri ve lisans sonras1 eğitim-öğretim düzeyinde önerilere yönelik çalışmalar olsa da, Türkçe derslerinin beceri alanları, ders materyalleri ve öğrenme-öğretme ortamları için böylesi bir çalışma, Alyılmaz ve Alyılmaz'ın 2018 yılında gerçekleştirdiği 'A ğız bilimi çalışmalarının Türkçe öğretimi açısından önemi’ adlı çalışma dışında, henüz söz konusu değildir. Bu anlamda bu çalışmanın alan yazına önemli katkı sağlayabileceği düşünülmektedir.

Bu bağlamda taranan 5-8 Türkçe ders kitaplarındaki metinlerde Türkiye Türkçesi ağızlarına dair yapılara yer verildiği tespit edilmiştir. Bu söz varlı̆̆ının özellikle nesnelerin bölgesel olarak adlandırılması ve ölçünlü Türkçe içinde yer alan bazı ünlem, yansıma söz ve fiil formlarının fonetik ve morfolojik bazı değişmelerle metinler içinde yer aldığı görülmüştür.

Bireylerin yetiştirilmesinde önemli sorumluluğu olan öğretmenlik mesleği, profesyonelliğin yanı sıra mesleğin gerektirdiği donanımlara, nitelik ve yeterliklere sahip olmayı gerektirir (Atunkeser 
ve Ünal, 2015). Bu bağlamda, Türkçe öğretmenlerine uygulanan Anadolu Ağızlarına Yönelik Tutum Ölçeğinde; 'ağızların eğitimdeki yeri ve işlevi', 'ağız kullanıcılarına yönelik tutum', ağız kullanımına yönelik duygusal değer' ve 'ağızların statüsü' faktörlerinde öğretmenler genel itibariyle olumlu bir tutum ortaya koymuşlardır. Bu da Türkçe öğretmenlerinin Türkiye Türkçesi ağızlarının, öğretim ortamlarının materyallerinde bir farkındalık unsuru olarak kullanılmasına yönelik olumlu duyuşsal bir tepki geliştirdiklerini göstermektedir.

Araştırmanın diğer önemli bir boyutu ise öğretmenlere dair sosyo-demografik değişkenlerin tutum puanlarıyla anlamlı bir ilişki ve fark ortaya koyup koymadığıdır. Yapılan analizlerde her iki cinsiyet ve tutum puanları; sosyal çevrelerinde ağız hususiyeti ile konuşan kişilerin varllğı ve tutum puanları arasında anlamlı bir ilişki olduğu, tutumlarının olumlu olduğu sonucuna ulaşılmıştır. Ayrıca tutum puanları ile meslek hayatının geçtiği yerleşim yerlerinden köy ve ilçede görev almış olan öğretmenler arasında Anadolu ağızları konusunda anlamlı bir fark ortaya çıkaran bir sonuç da elde edilmiştir. Bunların dişında kalan diğer değişkenlerle tutum puanları arasında anlamlı bir fark ve ilişkiye ulaşılamamıştır. Bu çalışmanın değişkenlerinin başka bir bölgede başka bir örneklem gruba uygulanması halinde anlamlı bir fark ve ilişki elde edilebileceği gibi yeni ve başka değişkenler işe koşularak öğretmenlerin Anadolu ağızlarına yönelik tutum puanlarıyla bu yeni değişkenler arasında anlamlı bir farkın ve ilişkinin olup olmadığı araştırılabilir.

Araştırmada görüşülen öğretmenlerden elde edilen veriler bağlamında yapılan içerik analizinde; Türkçe öğretmenlerinin eğitim-öğretimde, ağız özelliklerinin olduğu metinlerin öğretim materyallerine zenginlik kazandıracağını düşündükleri yönünde sonuçlar elde edilmiştir. Ayrıca, öğretmenlerin Anadolu ağızları konusunda yeterli bilgi ve donanıma sahip olmadıkları görülmüştür. Ancak, kendilerine belli eğitimler verilip alan açıldığında en azından söz varlığı ve folklorik malzemenin derlenmesi konusundaki çalışmalara katılma hususunda isteklilik göstermişlerdir.

Günümüzde ağız çalışmalarının temelini derleme çalışmaları oluşturmaktadır. $\mathrm{Bu}$ derlemelerden elde edilen dilsel malzeme gerek ağız hususiyetlerinin belirlenmesinde gerekse bu söz varlığının ölçünlü dile kazandırılmasında başat bir rol üstlenmektedir. Dil çalışmaların önemli bir basamağını oluşturan ağız araştırmaları hem dilin geçirdiği aşamaları göstermesi bakımından çok önemli bir yere sahiptir. Sadece dil alanına değil; varlık bulduğu coğrafya ve topluma dair çok değerli bilgiler sunmakta, toplumun geçirdiği kültürel değişimi gözler önüne sermektedir. Ancak, bağlı olduğu standart dilden anlam, şekil, ses ve dizim yönüyle ayrılık gösteren ağızlar; eğitim ve iletişim araçlarının yaygınlaşması ile beraber e neredeyse yok olma durumundadır. Hali hazırda ağızlar varolan, yazı dilinde yer almamış olan birçok deyim, sözcük ve kalıp sözün tespiti, kayıt altına alınması derlenip yazıya geçirilmesi ve geniş çevrelerce bilinmesinin hem bu bilginin hem de kültürün kaybolmaması için elzemdir (Uysal, 2017). Bu nedenlerle derleme çalışmaları önemlidir. Bununla beraber bu söz varlığının öğrenme-öğretme ortamlarına ölçülü, kontrollü ve farkındalık oluşturacak şekilde getirilmesi bu malzemenin kuşaklar boyu aktarılmasını da sağlayacaktır.

Türkçe öğretiminin konuşma becerisi alanındaki hatalarından biri de yerel ağız kullanımıdır. Sınıf ortamında her öğrencinin yerel ağız özellikleri ile konuşması bir sorun olarak görülmese de öğrenme-öğretme ortamlarında ölçünlü konuşma ve yazı dilinin kullanılması hem bir zorunluluk hem de toplumun tamamına uyum için gereklidir. Bu doğrultuda, Türkiye Türkçesi ağızlarından Türkçe öğretiminde yararlanılmasının yolları araştırılmalı, ülkemizin bu zenginlik ve çeşitliliğine yönelik farkındalıklar da artırılmalıdır. Bununla birlikte, Türkiye Türkçesi ağız hususiyeti gösteren metinlerin eğitim-öğretim ortamının bir parçası haline getirilmesinde ve öğretmen, öğrenci farkındalıklarının artırılmasında şunlar yapılabilir:

- Öğretmenlik lisans programlarında, ağız bilimi ile derleme yöntem ve tekniklerine dair derslere yer verilebilir.

- Hizmet içi eğitim çalışmaları kapsamında üniversitelerin Türk Dili ve Edebiyatı ve Türkçe bölümlerinin ilgili anabilim dallarıyla iş birliği yapılarak çalışmalar yürütülebilir. 
- Ağız araştırmaları sırasında elde edilen ve belge niteliği taşıyan malzemeler ile yayımlanmış kitaplar elektronik ortamda öğretmenlerin istifadesine sunulabilir.

- Başta üniversiteler olmak üzere çeşitli kurumlar tarafından yapılan ağız araştırmaları ile ilgili bilgi şöleni, kongre, çalıştay, panel gibi etkinliklere Türkçe öğretmenlerinin katılımı sağlanabilir, Millî Eğitim Bakanlığı da bu konuda farkındalık oluşturacak çalışmalar düzenleyebilir.

- Türkçe ders kitaplarında Türkiye Türkçesi ağız özelliklerinin görüldüğü metinlere daha fazla yer verilebilir. Bu metinler araştırmamızda tespit ettiğimiz gibi edebî metinlerde var olduğu şekliyle kitaplarda gösterilebilir. $\mathrm{Bu}$ yapılırken işaretleme sorunu yani fonetik farklılaşma göz ardı edilmeli, seslerin fonetik işarete dönüştürülmesi yoluna gidilmemelidir. Ders kitabı hazırlık, etkinlik, tema değerlendirme soruları bölümleri farkındalık yaratacak şekilde düzenlenmeli ve sözlükle desteklenmelidir.

- TV dizileri, radyo programları, oyunlar, türküler gibi durumlarla ağız özellikleriyle bir şekilde karşılaşan öğrencilere en azından Eğitim Bilişim Ağı (EBA) vasıtasıyla Milli Eğitimin temel ilkeleriyle çelişmeyen dilsel malzeme sunulabilir.

\section{Kaynaklar}

Akar, A. (2006). Ağız araştırmalarında yöntem sorunları. Turkish Studies, 1(2), 41-53.

Alyılmaz, C. (2010). Türkçe öğretiminin sorunları. Turkish Studies, 5(3), 728-749.

Alyılmaz, S. ve Cengiz A. (2018). Ağız bilimi çalışmalarının Türkçe öğretimi açısından önemi. Türk Dünyası Dil ve Edebiyat Dergisi, 4, 7-38.

Altunkeser, F. ve Ünal, E. (2015). Sınıf öğretmeni adaylarının öğretmenlik mesleğine ilişkin tutumlarının çeşitli değişkenler açısından yordanması. Ahi Evran Üniversitesi Sosyal Bilimler Enstitüsü Dergisi, 2(1), 1-15

Bilgin, N. (2014). Sosyal bilimlerde içerik analizi teknikler ve örnek çalışmalar. Ankara: Siyasal Kitabevi.

Buluç, S. (1942). Anadolu ağızları bibliyografyası. Türkiyat Mecmuası, 7-8(1), 327-333.

Buran, A. (2002). Konuşma dili yazı dili ilişkileri ve derleme faaliyetleri. Türkbilig, 4, 97-104.

Creswell, J. W. (2003). Research design: Qualitative, quantitative, and mixed methods approaches (2nd ed.). Thousand Oaks, CA: Sage.

Demir, N. (2010). Türkçede varyasyon üzerine. Ankara Üniversitesi Dil ve Tarih-Coğrafya Fakültesi Türkoloji Dergisi, 17(2), 93-106.

Demir, N. (2002). Ağız terimi üzerine. Türkbilig, 4,105-116.

Demir, N. (2012). Türkçe ağız araştırmalarında bazı yöntem sorunları. Diyalektolog, 4, 1-8.

Demir, N. ve Emine Y. (2010). Türk dili el kitabı. Ankara: Grafiker Yayınları.

Eker, S. (2015). Çă̆daş Türk dili. Ankara: Grafiker Yayınları.

Ekiz, D. (2015) Bilimsel araştırma yöntemleri. Ankara: Anı Yayıncılık. 
Gemalmaz, E. (2010). Türkçenin derin yapısı. Haz. Cengiz Alyılmaz ve Osman Mert. Ankara: Belen.

Gülensoy, T. ve Alkaya, E. (2010). Türkiye Türkçesi ağızları bibliyografyast. Ankara: Akçağ Yayınları.

Gülsevin, G. (2010). Yaşayan ve tarihî Türkiye Türkçesi ağızları. İstanbul: Özel Kitaplar.

Chambers, J. and Peter T. (1998). Dialectology. Cambridge: Cambridge University Press.

Karahan, L. (2000). Ağız araştırmalarında sorunlar. Türkçenin Ağız Araştırmaları Bildirileri: 21-26. Haz. Sumru Özsoy ve Eser Taylan. İstanbul: Boğaziçi Yayınevi.

Karasar, N. (1998). Bilimsel araştırma yöntemi. Ankara: Nobel Akademi.

Korkmaz, Z. (1995). Anadolu Ağızları üzerindeki araştırmaların bugünkü durumu ve karşılaştığ1 sorunlar. Türk Dili Üzerine Araştırmalar, 2, 199- 221.

Korkmaz, Z. (2007). Türk dilinin eski kültür mirasının Anadolu ağızlarındaki devamı. Türk Dili Üzerine Araştırmalar, 3, 641-650.

Korkmaz, Z. (2017). Dil bilgisi terimleri sözlüğ̈̈. Ankara: TDK Yayınları.

Pehlivan, A. (2012). Öğretmen adaylarının Anadolu ağızlarına yönelik tutum ölçeğinin geçerlik ve güvenirlik çalışması. Bilig, 63,135-157.

Rickford, J. R. (2002). "How linguists approach the study of language and dialect. www.stanford.edu/ Rickford/paper/173_reading_1. Doc.

Ronelle, A. (2006). Dialectology. Erişim adresi: https://slaviccenters.duke.edu/sites/slaviccenters.duke.edu/files/media_items_files/8alexander. original.pdf. Erişim Tarihi: 04/01/2018

Seçer, İ. (2015). SPSS ve LISREL ile pratik veri analizi. Ankara: Anı Yayınc1lı.

Şencan, H. (2005). Güvenirlik analiz yöntemleri. Sosyal ve davranıssal ölçümlerde güvenirlik geçerlilik. Ankara: Seçkin yayıncılık.

Tekin, T. (2013). Makaleler-çağdaş Türk dilleri. Ankara: TDK Yayınları.

Türkçe Sözlük. (1988). Ankara: TDK Yayınları.

Uysal, İ. (2017). Kuzuören (Konya-Bozkır) ağzından derleme sözlügüne katkılar. Diyalektolog Ulusal Sosyal Bilimler Dergisi, 14, 79-85.

Ünalan, Ş. (2014). Kültür ve dil. Ankara: Nobel yayınları.

Ünal, K., Taşkaya, S. M. ve Ersoy, G. (2018). Suriyeli göçmenlerin yabancı dil olarak Türkçe öğrenirken karşılaştıkları sorunlar ve çözüm önerileri. Ahi Evran Üniversitesi Sosyal Bilimler Enstitüsü Dergisi, 4(2), 134-149.

Vardar, B. (2002). Açıklamalı dilbilim terimleri sözlügü̈. İstanbul: Multilingual Yayınları. 


\section{Extended Abstract}

\section{Introduction}

Language allows people to communicate their tendencies, ideas, knowledge and emotions as well as to organize their ideas. Despite the various levels of Turkish education in Turkey, it is known that to students have difficulty in using their native language, expressing themselves orally and in writing (Aly1lmaz, 2010). In this sense, it is known that there are many problems in teaching Turkish in the context of language-culture relationship. In particular, the fact that language teaching is also a culture teaching is not fully reflected in the curriculum and textbooks. There are structures that reflect the cultural values centuries ago and show that Turkish is a very rich language in terms of meaning (Ünalan, 2014). Not all of these structures exist in modest language, some of them live only in the dialects and variations, some of them have been compiled and have not become widespread even if they have been written.

\section{Methodology}

In this study, simultaneous mixed design was used, quantitative and qualitative data were collected and evaluated simultaneously. Attitude scale was conducted on 151 Turkish teachers, and a structured interview technique consisting of 13 questions developed by the researcher was carried out with 29 teachers out of the group. In addition, 2018-2019 academic year Turkish textbooks of $5^{\text {th }}, 6^{\text {th }}$, $7^{\text {th }}$ and $8^{\text {th }}$ grades were examined in terms of vocabulary of the Anatolian dialects/variations.

The data obtained through structured interview technique were analyzed by content analysis method. Descriptive statistics were used to make the irregular data collected through measurement convenient for interpretation, and the frequency and percentage distributions of the obtained data are shown in tables. The Attitude Scale for Anatolian Dialects Scale was conducted on 151 people. The data were found to meet the general conditions of a parametric test, and the mean, median and standard deviation values of the scale were analyzed. In the analysis of quantitative data, one-factor analysis of variance and t-test in SPSS were used.

\section{Findings}

The texts in the 5- $8^{\text {th }}$ Grade Turkish course books were scanned to see whether they include words or phrases that show Turkish dialects and shown in tables. These structures are; names, exclamations, conjunctions, onomatopoetic words and some verb forms that belong to certain regions. It was found that they were not used in only one or a few units, but were found randomly in the texts in many units. These texts can be one of the in-class texts of the related unit as well as one of the free reading texts. However, the vocabulary that belongs to variations is included in the genres such as poetry, story, memoir, conversation, essay, anecdotes.

The mean of the Attitude Scale towards Anatolian variations, which consist of 22 items, was analyzed in terms of median and standard deviation values. In order to determine the level of the scale items, Disagree 1.00-1.80, Disagree 1.81-2.60, Undecided 2.61-3.40, Agree 3.41-4.20, Strongly Agree 4.21-5.00 points intervals were taken into account. It can be said that participant Turkish teachers have a positive attitude towards Anatolian variations.

Finding of content analysis of interview forms were divided as; code, category and theme. Therefore; as a result we reached at 2 themes as;

1) Language, Learning and Academic Descriptions

2) Word and Life.

And 3 categories found are; 
1) The Use of Language Variation and Education

2) Vocabulary Competence and Knowledge

3) Values

In this regard, the codes for the $1^{\text {st }}$ category are; Necessity, Obligations, The need to communicate, The enrichment of learning environment, Cultural communication, Cultural transfer, Cultural codes, Ease of expression, Contribution to standard language.

The codes that found for the $2^{\text {nd }}$ category are; Language awareness; Contribution to studies on linguistic variations; Lifelong learning; Teacher training; Folklore, ethnology, history; Compilation and identification.

The codes that found for the $3^{\text {rd }}$ category are; Ability to express oneself; Love for Turkish; belonging / non-alienation; Being social and functional; Cultural awareness; Language use and attitude

\section{Results, Discussion and Recommendations}

Through this study, we concluded that the structures that belong to Turkish variations took place in the texts of Turkish course books of $5-8^{\text {th }}$ grades. It has been seen that this vocabulary is especially included in the texts with some regional and phonetic and morphological changes of some forms of exclamation, onomatopoeic words and verbs in local variations of Turkish. Through the Attitude Scale towards Anatolian Dialects, it was concluded, teachers had a positive attitude in terms of place and function of local variations and their being used in Turkish courses through texts.

Another important aspect of the study is whether the socio-demographic variables of teachers reveal a significant relationship and difference with attitude scores. In the analyzes, both gender and attitude scores; it is concluded that there is a significant relationship between the presence of people who speak by using language varieties in their social environment and having positive attitude toward language varieties. In addition, a significant difference was observed between the attitude points and the teachers who worked in the villages and districts from the settlement. A significant difference and relationship between the other variables and attitude scores could not be reached. If the variables of this study were applied to another sample group in another region, a meaningful difference and relationship could be obtained, and new and other variables could be recruited and the teachers' attitude points towards the Anatolian dialects to investigate whether there was a significant difference or relationship between these new variables.

As result of content analysis, we concluded that Turkish teachers think that texts in which language varieties were used would enrich the teaching materials and also increase cultural awareness. The teachers did not have sufficient knowledge and equipment about Anatolian dialects. They areeager to participate in studies on vocabulary and compilation of folkloric material.

Recommendations are as follow:

Courses on dialect studies and compilation methods can be included in teaching undergraduate programs.

Within the scope of in-service training activities of teachers, studies can be carried out in cooperation with the relevant departments of the Turkish Language and Literature and Turkish departments of universities. 